\title{
THE EFFECT OF PROFIT SHARING FINANCING AND QARDH FINANCING ON NET PROFIT SHARIA BANK IN INDONESIA
}

\author{
Dede Rapsanjani Maulana 1, Eva Theresna Ruchjana ${ }^{2}$, Dian Hakip \\ Nurdiansyah ${ }^{3}$
}

1,2,3 Universitas Singaperbangsa Karawang, Indonesia

$\triangle$ Corresponding Author:

Nama Penulis: Dede Rapsanjani Maulana

E-mail:1610631030073@student.unsika.ac.id

\section{Abstract}

This study aims to examine the effect of Profit Sharing Financing and Qardh Financing on Net Profit Sharia Commercial Bank. The method used is descriptive statistics with quantitative approach that is through the classical assumption test to analyze the data and multiple linear regression analysis to determine the level of relations or effect that given by Profit Sharing Financing and Qardh Financing on Net Profit and processed by using software SPSS 16. While data used are secondary data with quantitative data types during the period 20142019. Population of this study is Sharia Commercial Bank companies with sampling method that is purposive sampling, so that the number of observations obtained as many as 6 companies. Based on the result of the research, the test of simultaneously results with the statistical test show that the variable Profit Sharing Financing and Qardh Financing simultaneously affected. The result of coefficient determination shows that Net Profit $(Y)$ is influenced by Profit Sharing Financing (X1), Qardh Financing (X2) as much as $64.1 \%$ and the remaining left is influenced by other variables as much as $35.9 \%$.

Key Words: Profit Sharing Financing, Qardh Financing, Net Profit.

\section{Abstrak}

Penelitian ini bertujuan untuk menguji Pengaruh Pembiayaan Bagi Hasil dan Pembiayaan Qardh pada Laba Bersih Bank Umum Syariah. Metode Yang digunakan adalah statistik deskriptif dengan pendekatan kuantitatif yaitu melalui uji asumsi klasik untuk menganalisis data dan regresi linier berganda analisis untuk mengetahui tingkat hubungan atau pengaruh yang diberikan oleh Pembiayaan Bagi Hasil dan Pembiayaan Qardh atas Laba Bersih dan diolah dengan menggunakan software SPSS 16. Sedangkan data yang digunakan adalah data sekunder dengan jenis data kuantitatif selama periode 2014-2019. Populasi penelitian ini adalah perusahaan Bank Umum Syariah dengan metode pengambilan sampel yaitu purposive sampling, jadi jumlah observasi yang diperoleh sebanyak 6 perusahaan. Berdasarkan hasil penelitian, pengujian hasil secara simultan dengan uji statistik menunjukkan bahwa variabel Pembiayaan Bagi Hasil dan Pembiayaan Qardh berpengaruh 
Dede Rapsanjani Maulana: The Effect of Profit Sharing Financing and Qardh Financing

secara simultan. Hasil koefisien determinasi menunjukkan bahwa Laba Bersih (Y) dipengaruhi oleh Pembiayaan Bagi Hasil (X1), Pembiayaan Qardh (X2) sebesar $64,1 \%$ dan sisanya dipengaruhi oleh variabel lain sebesar $35,9 \%$.

Kata Kunci: Pembiayaan Bagi Hasil, Pembiayaan Qardh, Laba Bersih.

\section{INTRODUCTION}

The emergence of the term Islamic Economy or Sharia Economy in Indonesia began in 1992 which was initially based on the majority of Indonesia's Muslim population. The founder of sharia banking in Indonesia was Bank Muamalat. The bank was founded by the Indonesian Ulema Council, the Indonesian Muslim Intellectuals Association (ICMI), as well as Muslim entrepreneurs and not forgetting the government. Entering in 1990, MUI formed a working group to establish an Islamic Bank in Indonesia, this was the forerunner to the birth of Islamic banking in Indonesia, which was later named the Indonesian Mualat Bank (Bank Muamalat Indonesia). When the economic crisis in 1998, the bankers were very confused why Bank Muamalat Indonesia could survive the crisis that made many conventional banks lethargic (Al-Qurtuby, 2020).

The purpose of this study is to provide input to Islamic Commercial Banks in managing, acting and making decisions wisely in providing and cooperating with customers both in profit sharing financing and Qardh financing which can affect the net profit of Islamic Commercial Banks and create a prosperous life Public.

Based on the data the author obtained, the net profit of Islamic Commercial Banks in 2014 - 2019, moving in a fluctuating manner, tends to increase. It is shown by Table 1 . When viewed annually, in 2014 the figure was 702 billion. And in 2015 it decreased by only getting a value of 635 billion. Then it continued to increase in 2016 - 2019, amounting to 952 billion, 990 billion, 2,806 billion and 4,195 billion.

Table 1. Net Profit Growth Period 2014-2019 (In billion)

\begin{tabular}{lcccccc}
\hline & $\mathbf{2 0 1 4}$ & $\mathbf{2 0 1 5}$ & $\mathbf{2 0 1 6}$ & $\mathbf{2 0 1 7}$ & $\mathbf{2 0 1 8}$ & $\mathbf{2 0 1 9}$ \\
\hline $\begin{array}{l}\text { Net } \\
\text { Profit }\end{array}$ & 702 & 635 & 952 & 990 & 2,806 & 4,195 \\
\hline
\end{tabular}

Source : SPS, OJK (2020) 
Dede Rapsanjani Maulana: The Effect of Profit Sharing Financing and Qardh Financing

Meanwhile, based on data from the Sharia Banking Statistics, the profit sharing financing for 2014 - 2019 has increased. As for the qardh financing in 2014 - 2016 it has decreased, and for 2017 - 2019 it has increased.

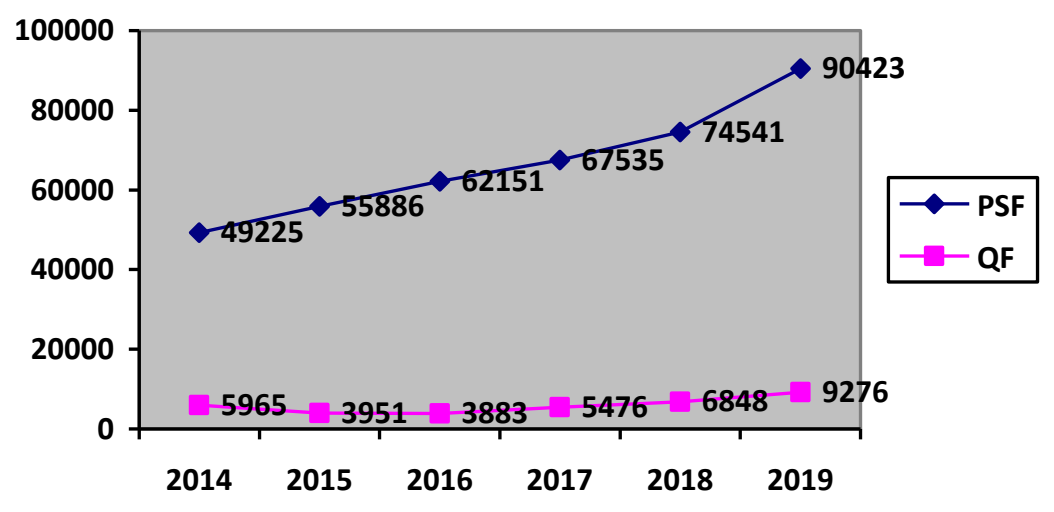

Figure 1. Graphic Profit Sharing Financing and Qardh Financing Source : SPS, OJK (2020)

Figure 1 show the financing of profit sharing from 2014 - 2019 there has been an increase, including 49.225 in 2014, 55.886 in 2015, 62.151 in 2016, 67.535 in 2017, 74.541 in 2018 and 90.423 in 2019. Whereas for qardh financing, it can be seen from Figure 2 above, that it experienced a decline in 2014 - 2016, including 5.965, 3.951, and 3.883. For 2017 - 2019 there was an increase, namely 2017 amounting to 5.476, 2018 amounting to 6.848 and in 2019 amounting to 9.276 .

Based on previous research, there are some differences in the results of studies, according to Kholidah (2018) Profit sharing Financing and Qardh Financing have no significant effect to Net Profit. According to Ariyani (2014) Profit Sharing Financing (Mudharabah-Musyarakah) significantly affected to Net Profit while Qardh Financing have no significant effect on Net Profit and According Profit Sharing Financing has a significant positive effect on net profit (Puspasari \& Mawardi, 2014).

Based on the explanation that has been described, the researcher believes that the research to be carried out has a good impact on net profit and public trust in Islamic Commercial Banks.

\section{LITERATURE REVIEW}

Islamic banking or Islamic banking is a financial system that bridges between those who need funds and those who have excess funds through 
Dede Rapsanjani Maulana: The Effect of Profit Sharing Financing and Qardh Financing

financial products and services that are in accordance with Sharia principles. All transactions that occur in Sharia financial activities must be carried out based on Sharia principles. Sharia Principles are principles that are based on the teachings of the Qur'an and Assunnah (Iskandar, 2017).

Understanding Profit One of the goals of a profit-oriented organization is to make a profit. Profit is even one that is a measure of performance for a particular part of an organization. Profit is a component in financial statements which is highly highlighted by the users of financial statements (Festiani, 2016).

Profit Sharing Financing for Sharia banks (Nurmawati et al., 2020). Profit-based and principled financing can increase community economic empowerment and can improve people's welfare (Wu et al., 2020). If the welfare of the community increases, it will increase public funds raised by Islamic banks and can increase funding disbursed by Islamic banks . Channeling of funds carried out by Islamic banks can produce benefits for customers and Islamic banks, in the form of agreed profit sharing. This shows that the greater the funds channeled by Islamic banks to the community, it can increase the revenue and net profit of Islamic banks.

In connection with Bank Indonesia Regulation Number 10/17/PBI/ 2008 concerning Sharia Bank Products and Sharia Business Units concerning Qardh. Qardh is a contract for the distribution of funds by a Sharia Bank or Sharia Business Unit to a customer as a debt receivable provided that the customer is required to return the funds to the Sharia Bank or Sharia Business Unit at the agreed time.

The results of this study have the same results as the existing research conducted by Kholidah (2018) that Profit Sharing Financing does not affect the acquisition of Net Profit. This means that the size of the Profit Sharing Financing will not change the net profit. While According to Puspasari and Mawardi (2014) Profit Sharing Financing has a significant positive effect on net Profit.

While the research in this study have contradicted with the results research by Kholidah (2018) that Qardh Financing does not affect on Net Profit. But according The results of this study are in line with the results of research conducted by Priatna and Rosalina (2019) which state that if Qardh Financing increases it will affect to Net Profit. That It can be explained that when Qardh Financing increases, the net profit will increase, and vice versa. 
Dede Rapsanjani Maulana: The Effect of Profit Sharing Financing and Qardh Financing

\section{METHOD}

In this study, researchers used a descriptive verification method with a quantitative approach. In this study, researchers used purposive sampling method for sampling. Whereas in the data analysis process in this study used data analysis with SPSS software consisting of classical assumption tests (normality test, autocorrelation test, heteroscedasticity test and multicollinearity test), multiple linear regression analysis, hypothesis testing (statistical t test and $\mathrm{f}$ test statistics) and the coefficient of determination (R2). Table 2 show the research variable, as follows.

Table 2. Research Instrument

\begin{tabular}{|c|c|c|c|}
\hline Variable & Variable Definition & Scale & Measurement \\
\hline $\begin{array}{l}\text { Y variable } \\
\text { Net profit }\end{array}$ & $\begin{array}{l}\text { Net Income is operating } \\
\text { income plus non- } \\
\text { operating income, minus } \\
\text { non-operating costs, and } \\
\text { minus income tax } \\
\text { (Choiruddin, 2017) }\end{array}$ & Rasio & $\begin{array}{l}\text { Net Income = income- } \\
\text { expenses }\end{array}$ \\
\hline $\begin{array}{l}\text { Variable X } \\
\text { Profit Sharing } \\
\text { Financing (X1) }\end{array}$ & $\begin{array}{l}\text { The agreement between } \\
\text { the Bank as the owner of } \\
\text { capital with Nasbah as the } \\
\text { manager of capital to } \\
\text { obtain profits and share } \\
\text { profits based on the } \\
\text { agreed agreement or Ratio } \\
\text { (Puteri \& Solekah, 2018) }\end{array}$ & Ratio & $\begin{array}{l}\text { Profit Sharing } \\
\text { Financing } \\
\text { measured by an } \\
\text { indicator of the } \\
\text { amount of Profit } \\
\text { Sharing obtained } \\
\text { from the financial } \\
\text { statements of a Sharia } \\
\text { commercial bank. }\end{array}$ \\
\hline $\begin{array}{l}\text { Qardh Financing } \\
\text { (X2) }\end{array}$ & $\begin{array}{l}\text { Qardh is a contract for the } \\
\text { distribution of funds by a } \\
\text { Sharia Bank or Sharia } \\
\text { Business Unit to a } \\
\text { customer as a debt } \\
\text { receivable provided that } \\
\text { the customer is required } \\
\text { to return the funds to the } \\
\text { Sharia Bank or Sharia } \\
\text { Business Unit at the } \\
\text { agreed time. } \\
\text { Bank Indonesia Regulation } \\
\text { Number 10/17 / PBI / } \\
2008\end{array}$ & Ratio & $\begin{array}{l}\text { Qardh financing is } \\
\text { measured by an } \\
\text { indicator of the } \\
\text { amount of Qardh } \\
\text { financing obtained } \\
\text { from Islamic } \\
\text { commercial bank } \\
\text { financial statements. }\end{array}$ \\
\hline
\end{tabular}

Source : by researcher, (2020) 
Dede Rapsanjani Maulana: The Effect of Profit Sharing Financing and Qardh Financing

\section{RESULT AND DISCUSSION}

This chapter describes the results of data processing. The next is to interpret each stage. Linear regression analysis is a part of parametric analysis. Parametric analysis requires a classic assumption test. In this study, the classical assumption test includes assumptions for normality, homogeneity, autocorrelation, multicollinearity, and linearity.

\section{Classic Assumption Test}

The classical assumption test is a statistical requirement that must meet in multiple linear regression analysis based on the ordinary least square (OLS). So, a regression analysis is not based on OLS does not require classical assumptions, such as logistic regression or ordinal regression. Likewise, not all classical assumption tests must be carried out in linear regression analysis. For example, multicollinearity tests are not carried out on simple linear regression analysis. Autocorrelation tests do not need to be applied to cross-sectional data (Supian \& Bon, 2019).

Normality Test with the Kolmogorov-Smirnov test shows that the value obtained by Asymp. Sig is 0.125 which means that the data has an Asymp value. Sig is greater than the Sig level $(0.125>0.05)$. It concludes that the data used or processed is normally distributed. The homogeneity test used the Glejser test. The results of the Glejser test showed that the regression analysis was homogeneous. It indicates that there is no difference in variance between observations. Autocorrelation test with Durbin-Watson. It can be seen that the Durbin-Watson value is 1.569 , thus the Durbin-Watson value is in the intervals of -2 and $+2(-2<1.569<2)$ so that it can be concluded that there is no autocorrelation in the regression model. Multicollinearity Test use the VIF value of each independent variable, namely Profit Sharing Financing and Qardh Financing, is 1,656 so that it can be seen that for all independent variables the VIF value is below 10. For the Tolerance value obtained by each independent variable, namely Profit Sharing Financing and Qardh Financing is 0.604 so it can be seen that for all independent variables, the Tolerance value is above 0.1. From the VIF and Tolerance values obtained, it can be concluded that no there is multicollinearity between independent variables in the regression model.

\section{Multiple Linear Regresion}

Regression analysis deals with the dependence of one variable on another. Kendal and Stuart said that 'A statistical relationship, although 
Dede Rapsanjani Maulana: The Effect of Profit Sharing Financing and Qardh Financing

strong and suggestive, can never form a causal relationship because the causal relationship comes from theory or other sources (Kendall et al., 2019). Based on the results of the above processing, the results of the multiple linear regression analysis equation are as follows:

(Net Profit) $Y=76834,686-0.003+0.157+e$

From the Multiple Linear Regression equation above, it is known that the constant value is 78834,686 . This shows thatAll independent variables, namely Profit Sharing Financing (X1) and Qardh Financing (X2) are assumed to be in a constant state, so the dependent variable (Net Profit) is 78834,686. The Profit Sharing Financing regression coefficient of -0.003 shows that the regression coefficient of the Profit Sharing Financing variable is increased by 1 point, then the Net Profit will decrease by 0.003 . Regression Coefficient Qardh Financing of 0.157 shows that the variable regression coefficient of Qardh Financing is increased by 1 point, then the Net Profit will increase by 0.157 .

\section{Partial Test (t-Test)}

The partial test is statistical analysis in multiple regression, which is used to determine the effect of independent variables individually (partially) on the dependent variable (Y) (Indriastuti \& Ifada, 2019). To examine whether $\mathrm{X}$ effect on $\mathrm{Y}$ is significant or not, it requires a t-statistics value or a sig value. Table 3 shows the result of partial test.

To find the ttable value using the following formula $T_{\text {table }}=t(a / 2 ; n-k-1)$. From the formula above, it can be concluded that $\mathrm{t}$ table $=\mathrm{t}(0.025 ; 33)=$ 2,03224 . After getting the $t$ table value, conclusions can be made to accept or reject the hypothesis.

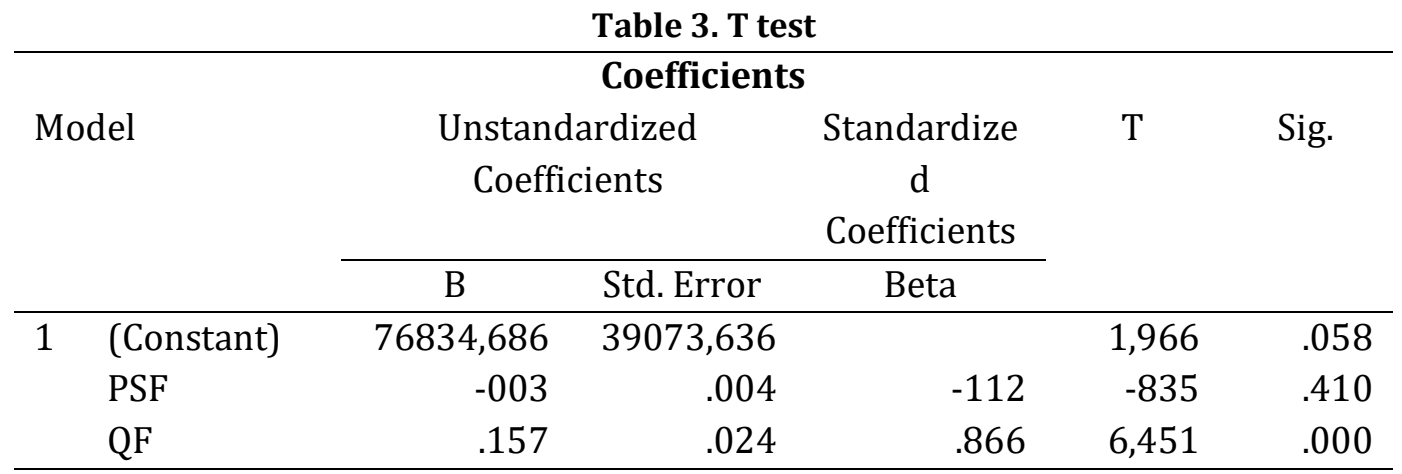

a. Dependent Variable: Net Profit

Source: Data processed by researchers, 2020 
Based on the test results, the tcount value is $-0,835$. When compared with the value of $t$ table which is 2,03224 . So that the value of tcount $-0,835$ less than t-table value of 2,03224. And a significance value of 0.410 is greater than 0,05 . Thus, $\mathrm{H} 1$ was rejected. Which means that there is no influence between the financing for results on net income.

The effect of Qardh financing on net income show that the significant effect. Based on the test results, the tcount value is obtained. When compared with the t-table value of 6,451 . So that the tcount value of $6,451>$ the t-table value 2,03224 . And the significance value of 0,000 is smaller than 0,05 . Thus it can be concluded that $\mathrm{H} 2$ is accepted, which means that there is a positive influence between Qardh financing on net income.

\section{Simultaneously Test}

Table 4 shows the result of F-test. Based on Table 4 , the F test shows a significance value of 0,000 with an $\alpha$ value of 0,05 . So it can be concluded that the significance value smaller than the $\alpha$ value $(0,000<0,05)$, thus $\mathrm{H} 0$ is rejected and Ha accepted. From table 7 above, first the values of Ftable must be determined. The value of the F-table can be determined using the following formula $F_{\text {table }}=\mathrm{F}(\mathrm{k} ; \mathrm{n}-\mathrm{k})$. Ftable in this study is $\mathrm{F}$ table $=\mathrm{F}(2 ; 36)=$ 3,28. Furthermore, the value of Fcount with the value of Ftable. So that the value is $29,414>3,28$. That is, the value of Fcount is greater than the value of Ftable. The significance value of 0,000 is less than 0,05 . Thus, it can be concluded that there is an effect of sharing financing and qardh financing simultaneously (Yusuf et al., 2019).

\section{Coefficient Determination $\left(\mathbf{R}^{2}\right)$}

Table 5 shows the result of coefficients determination. Based on the results of the calculation of the table above, it can be seen that the value obtained for $\mathrm{R}$ Square is 0.641 or $64.1 \%$. This shows that the variables studied, namely Profit Sharing Financing, and Qardh Financing, have an effect of only $64.1 \%$ on the Net Profit.

Table 4. F-test

\begin{tabular}{llcrlll}
\hline \multicolumn{7}{c}{ ANOVAb } \\
\hline \multicolumn{1}{l}{ Model } & Sum of & Df & Mean & F & Sig. \\
& & Squares & & Square & & \\
1 & Regression & $1.416 \mathrm{E} 12$ & 2 & $7.078 \mathrm{E} 11$ & 29,414 & $.000 \mathrm{a}$ \\
& Residual & $7.941 \mathrm{E} 11$ & 33 & $2.406 \mathrm{E} 10$ & & \\
& Total & $2.210 \mathrm{E} 12$ & 35 & & & \\
\hline
\end{tabular}

Source: Data processed by researchers, 2020 
Dede Rapsanjani Maulana: The Effect of Profit Sharing Financing and Qardh Financing

While the remaining $35.9 \%$ is influenced by variables not examined in this study.

Table 5. Determination Coefficient Test (R2)

\begin{tabular}{lcccr}
\hline Model & $\mathrm{R}$ & $\mathrm{R}$ Square & $\begin{array}{c}\text { Adjusted R } \\
\text { Square }\end{array}$ & $\begin{array}{c}\text { Std. Error of the } \\
\text { Estimate }\end{array}$ \\
\hline 1 & $.800 \mathrm{a}$ & .641 & .619 & 155123,759 \\
\hline \multicolumn{4}{c}{ Source: Data processed by researchers, $\mathbf{2 0 2 0}$}
\end{tabular}

\section{Discussion}

The results of this study have the same results as the existing research conducted by Kholidah (2018) that Profit Sharing Financing does not affect the acquisition of Net Profit. This means that the size of the Profit Sharing Financing will not change the net profit. While According to Puspasari \& Mawardi (2014) Profit Sharing Financing has a significant positive effect on net Profit.

It does not affect Profit Sharing Financing according to Hidayat from Faculty of Economics University of Indonesia reported that The problem of low profit sharing financing in Indonesia can come from various sources, namely internal Islamic banks, stakeholders, regulations, and other external factors (Wibowo \& Syaichu, 2013). But in this article, focus more on the internal side of Islamic banks. The Center for Central Banking Education and Studies (PPSK) of Bank Indonesia in 2004, once conducted a study that there are five internal problems of Islamic banks that arise around the low profit sharing financing in Islamic banking, namely: First, the understanding of Islamic bankers of the essence of Islamic banking is lacking. Second, Islamic banks prioritize business and profit orientation too much. Third, the quality and quantity of human resources is inadequate and does not master the ins and outs of distribution of profit-sharing financing. Fourth, Aversion to effort, that is, Islamic banks still do not want to be bothered or do extra things in assisting entrepreneurs. Fifth, aversion to risk, namely Islamic banks are still avoiding risk.

While the research in this study have contradicted with the results research by Kholidah (2018) that Qardh Financing does not affect on Net Profit. But according The results of this study are in line with the results of research conducted by (Priatna \& Rosalina, 2019) which state that if Qardh Financing increases it will affect to Net Profit. That It can be explained that when Qardh Financing increases, the net profit will increase, and vice versa. 
According to Yunus said that the development of sharia banking products to help people perform the pilgrimage is Qardh ONH or more popularly known as hajj bailout funds. Qardh's definition in the MUI DSN Fatwa No. 19 of 2001 is a loan agreement to the customer provided that the customer is required to return the funds received to the Sharia Financial Institution at the time agreed by the Sharia Financial Institution and the customer.

\section{CONCLUSION}

Based on the identification and formulation of the problems that have been discussed previously, the results of the research and discussion can be concluded. Statistically, Profit Sharing Financing (PSF) has no significant effect on the Net Profit of Islamic Commercial Banks for the 2014-2019 period as measured by the total Mudharabah and Musyarakah financing. So that fluctuations and whatever the value of Profit Sharing Financing (PSF) does not have a significant effect on fluctuations in Net Profit. Qardh Financing $(\mathrm{QF})$ has a statistically significant positive effect on the Net Profit of Islamic Commercial Banks for the 2014-2019 period as measured by the total Qardh financing. This shows that the fulfillment and increase of Qardh Financing will optimize the company's profitability or in other words increase the Net Profit value, this indicates that the image of Islamic Commercial Banks in the eyes of the public is getting better every year. Simultaneously there is a significant influence between the PSF and QF on the Net Profit of Islamic Commercial Banks for the 2014-2019 period of 64.1\%.

\section{REFERENCES}

Al-Qurtuby, S. (2020). Islam dan Sistem Perbankan di Timur Tengah dan Indonesia. Semarang : Elsa Press.

Ariyani, D. (2014). Analisis Pengaruh Pertumbuhan Pembiayaan Murabahah, Bagi Hasil Dan Pinjaman Qardh Terhadap Pertumbuhan Laba Bersih Pada Bank Syariah Periode Triwulan I 2011 Sampai Triwulan Iv 2013. Jurnal Umrah, Vol. 31, No. 2, Hal. 13.

Choiruddin, M. N. (2017). Analisis Debt To Equity Ratio (Der), Return On Assets (Roa), Return On Equity (Roe), Net Profit Margin (Npm) Terhadap Stock Price (Harga Saham) Pada Perusahaan Saham Syariah Sektor Makanan Dan Minuman Periode Tahun 2013-2016. El Dinar: Jurnal Keuangan dan Perbankan Syariah, Vol. 5, No. 2, Hal. 27-43. 
Dede Rapsanjani Maulana: The Effect of Profit Sharing Financing and Qardh Financing

Festiani, E. R. (2016). Analisis Pengaruh Rasio CAR, NPF, BOPO, ROA dan FDR terhadap tingkat Kesehatan Bank Umum Syariah di Indonesia. El Dinar: Jurnal Keuangan dan Perbankan Syariah, Vol. 4, No. 2, Hal. 196211.

Finnerty, J. D. (2011). Project Financing: Asset-Based Financial Engineering. John Wiley \& Sons.

Indriastuti, M., \& Ifada, L. M. (2019). The Effect of Non-Performing Financing on Sharia BPR Performance. Hal. 152-154.

Iskandar, E. (2017). Aplikasi Sistem Keuangan Syariah Pada Perbankan. Almufida: Jurnal Ilmu-Ilmu Keislaman, Vol . 2, No. 2.

Islamic Finance: Understanding its Principles and Practices-Daud Vicary Abdullah, Keon Chee-Google Buku. (n.d.). Retrieved October 27, 2020,

Kendall, L. K., Rader, R., Gagic, V., Cariveau, D. P., Albrecht, M., Baldock, K. C. R., Freitas, B. M., Hall, M., Holzschuh, A., Molina, F. P., Morten, J. M., Pereira, J. S., Portman, Z. M., Roberts, S. P. M., Rodriguez, J., Russo, L., Sutter, L., Vereecken, N. J., \& Bartomeus, I. (2019). Pollinator size and its consequences: Robust estimates of body size in pollinating insects. Ecology and Evolution, Vol. 9, No. 4, Hal. 1702-1714.

Kholidah, H. (2018). The Effect of Social Performance to the Profitability of Islamic Banks. TIJAB (The International Journal of Applied Business), Vol. 2, No. 2, Hal. 58-68.

Nurmawati, B. A., Rahman, A. F., \& Baridwan, Z. Z. (2020). The Moderating Role Of Intellectual Capital On The Relationship Between Non Profit Sharing Financing, Profit Sharing Financing And Credit Risk To Financial Performance Of Islamic Bank. Jurnal Reviu Akuntansi Dan Keuangan, Vol. 10, No. 1, Hal. 38-52.

Pandia, F. (2012). Manajemen Dana dan Kesehatan Bank. Jakarta: Rineka Cipta.

Priatna, H., \& Rosalina, A. (2019). Pengaruh Piutang Qardh Dan Perputaran Kas Terhadap Laba Bersih Pada Pt. Bprs Al-Ihsan. Akurat / Jurnal Ilmiah Akuntansi FE UNIBBA, Vol. 10, No. 3, 17-30.

Puspasari, R., \& Mawardi, I. (2014). Pengaruh Kinerja Sosial Terhadap Profitabilitas Bank Syariah. Jurnal Ekonomi Syariah Teori Dan Terapan, 1(7), 456-468.

Puteri, S. I. L., \& Solekah, N. A. (2018). Pengaruh pembiayaan murabahah dan musyarakah melalui kredit bermasalah terhadap likuiditas bank umum syariah. El Dinar Jurnal Keuangan dan Perbankan Syariah, 6(1), $1-12$.

Ryandono. (2010). Peran dan Pengaruh Penghimpunan Dana dan Penyaluran

Dana Serta Kinerja Bank terhadap Karyawan Bank Islam Perspektif

Maqashid Syariah di Indonesia. Disertasi: Universitas Airlangga

Surabaya.

Supian, S. S., \& Bon, A. T. (2019). Classical Assumption Test for Testing the Influence of Composite Stock Price Index, Inflation Level, BI Rate, and 
Dede Rapsanjani Maulana: The Effect of Profit Sharing Financing and Qardh Financing

Rupiah Exchange Rate Toward Stock Price in Indonesia. Saudi Arabia, 7.

Wibowo, E. S., \& Syaichu, M. (2013). Analisis Pengaruh Suku Bunga, Inflasi, Car, Bopo, Npf Terhadap Profitabilitas Bank Syariah. Diponegoro Journal of Management, 2(2), 10-19.

Wu, Y., Zhu, J., Yuan, Y., \& Cheng, D. (2020). Profit Sharing Method for Participants in Cloud Energy Storage. 2020 12th IEEE PES Asia-Pacific Power and Energy Engineering Conference (APPEEC), 1-5.

Yusuf, D., Hamdani, \& Kholik, K. (2019). The Effect of Buy and Sell Financing (Murabahah), Profit Share Financing (Mudarabah), Equity Capital Financing (Musyarakah) and Non-Performing Financing Ratio on Profitability Level of Sharia Commercial Banks in North Sumatera. Britain International of Humanities and Social Sciences (BIoHS) Journal, 1(1), 81-88. 